https://doi.org/10.17816/MAJ191S1107-108

\title{
IMPACT OF RONCOLEUKIN (RIL-2) \\ ON THE LYMPHOCYTE-TRIGGERING ACTIVITY \\ OF MACROPHAGES AFTER TRAUMATIC BRAIN INJURY IN VARIOUSLY AGED RATS
}

\author{
S.N. Shanin ${ }^{1}$, N.B. Serebryanaya ${ }^{1,2,3}$, T.A. Filatenkova ${ }^{1}$, E.E. Fomicheva ${ }^{1}$ \\ ${ }^{1}$ Institute of Experimental Medicine, Saint Petersburg, Russia; \\ ${ }^{2}$ Saint Petersburg State University, Saint Petersburg, Russia; \\ ${ }^{3}$ North-Western State Medical University named after I.I. Mechnikov, Saint Petersburg, Russia

\section{ВЛИЯНИЕ ЧМТ И РОНКОЛЕЙКИНА У КРЫС РАЗНОГО ВОЗРАСТА НА ЛИМФОЦИТ-АКТИВИРУЮЩУЮ АКТИВНОСТЬ МАКРОФАГОВ} \\ С.Н. Шанин ${ }^{1}$, Н.Б. Серебряная ${ }^{1,2,3}$, Т.А. Филатенкова ${ }^{1}$, Е.Е. Фомичева ${ }^{1}$ \\ ${ }^{1}$ ФГБНУ «Институт экспериментальной медицины», Санкт-Петербург; \\ ${ }^{2}$ Санкт-Петербургский государственный университет, Санкт-Петербург; \\ ${ }^{3}$ ФГБОУ ВО «Северо-Западный государственный медицинский университет им. И.И. Мечникова» \\ Минздрава России, Санкт-Петербург \\ shanins@yandex.ru \\ IL-1 $\beta$ is involved in both brain damage process and the mechanisms of brain regeneration processes. \\ The goal of the present research is to measure the change in the production of lymphocyte-activating fac- \\ tor (LAF) after experimental traumatic injury (TBI) in variously aged rats and evaluate the possibility to \\ correct LAF production with roncoleukin (rIL-2). LAF activity in the supernatants of peritoneal macrophages \\ of injured rats was measured by its ability to have comitogenic effect on the proliferation of rat thymocytes \\ stimulated by suboptimal lectin doses. LAF stimulation index was defined as ratio of stimulated to unstimu- \\ lated levels of LTF. Results and discussion. The strongest suppression of microphages' cytokine-producing \\ function was found in older rats after TBI. rIL-2 injection significantly reversed the injuries caused by TBI \\ even in older rats. These data confirm that exogenic IL-2 is able to activate the functional characteristics of \\ innate immunity cells and that is has a normalizing effect on the immune cells of the older animals.
}

Keywords: lymphocyte-activating factor; traumatic brain injury; roncoleukin.

ИЛ-1ß вовлечен в процессы повреждения мозга, а также участвует в механизмах реализации восстановительных процессов в мозге. Цель исследования - показать возможность определения продукции перитонеальными макрофагами (МФ) лимфоцит-активирующего фактора (ЛАФ), включающего в себя определение активности ИЛ-1, для функциональной характеристики МФ при ЧМТ у крыс разного возраста и оценки влияния на продукцию ЛАФ ронколейкина - рекомбинантного препарата ИЛ-2 (rIL-2). Материалы и методы. Активность ЛАФ в супернатантах перитонеальных макрофагов травмированных животных оценивалась по их способности оказывать комитогенное действие на пролиферацию тимоцитов мышей, стимулированных субоптимальными дозами лектинов. Индекс стимуляции МФ определялся как отношение показателей стимулированного к нестимулированному уровню ЛАФ. Результаты и выводы. Показано, что наиболее выраженное угнетение цитокин-продуцируюшей функции макрофагов было выявлено у старых крыс, получивших ЧМТ. Введение rIL-2 в значительной степени реверсировало развившиеся после травмы изменения, в том числе и у старых животных. Полученные данные подтверждают представление о нормальной реакции клеток врожденного иммунитета животных на экзогенный IL-2 и его нормализующем действии на иммунные клетки старых животных.

Ключевые слова: лимфоцит-активирующий фактор; черепно-мозговая травма; ронколейкин.

Introduction. IL-1 $\beta$ is involved in both brain damage process and the mechanisms of brain regeneration [1]. IL-1 $\beta$ also has immunnoprotective effect on immunosuppression induced by glucocorticoids and stress after trauma [2]. Along with other proinflammatory cytokines, IL- $1 \beta$ is produced by peritoneal macrophages. Their activity may be measured with the lymphocyte-activating factor (LAF) test. The goal of the present research is to measure the change in the production of lym- phocyte- activating factor (LAF) after experimental traumatic brain injury (TBI) in variously aged rats and evaluate the possibility to manage LAF production with roncoleukin (rIL-2).

Material and methods. After TBI (inflicted by a falling weight) the animals were injected with rIL-2 (30 $\mathrm{mkg} / \mathrm{kg}, 3$ days). LPS-induced macrophage was used to induce LAF. LAF activity in supernatants was measured by their ability to have comitogenic effect on the proliferation of rat thymocytes stimu- 
Table 1

LAF production of macrophages young ( $\mathrm{Y}, 3$ months old) and old $(0,18$ months old) rats after the application of TBI and the injection of rlL-2

\begin{tabular}{|l|c|c|c|c|}
\hline \multicolumn{1}{|c|}{ Animal groups } & Age & unstLAF & stLAF & SI of LAF \\
\hline \multirow{2}{*}{ intact } & Y & $0.95 \pm 0.09$ & $1.67 \pm 0.11$ & $1.75 \pm 0.16$ \\
\cline { 2 - 5 } & $\mathrm{O}$ & $0.86 \pm 0.09$ & $1.95 \pm 0.16$ & $2.27 \pm 0.21^{\#}$ \\
\hline \multirow{2}{*}{$7^{\text {th }}$ day after TBI } & $\mathrm{Y}$ & $1.81 \pm 0.38^{*}$ & $1.44 \pm 0.27$ & $0.79 \pm 0.22^{*}$ \\
\cline { 2 - 5 } & $\mathrm{O}$ & $0.78 \pm 0.22^{\#}$ & $1.01 \pm 0.19^{*}$ & $1.29 \pm 0.15^{*}$ \\
\hline $7^{\text {th }}$ day after TBI + injection of rIL-2 & $\mathrm{Y}$ & $1.22 \pm 0.33$ & $2.23 \pm 2.18$ & $1.83 \pm 0.25$ \\
\cline { 2 - 5 } & $\mathrm{O}$ & $0.56 \pm 0.18^{\#}$ & $0.98 \pm 0.22^{*}$ & $1.75 \pm 0.28$ \\
\hline \multirow{2}{*}{$4^{\text {th }}$ day after TBI } & $\mathrm{Y}$ & $1.32 \pm 0.35$ & $1.45 \pm 0.51$ & $1.1 \pm 0.33$ \\
\cline { 2 - 5 } & $\mathrm{O}$ & $0.75 \pm 0.35$ & $0.66 \pm 0.22^{* \#}$ & $0.88 \pm 0.20^{*}$ \\
\hline \multirow{2}{*}{$14^{\text {th }}$ day after TBI + injection of rIL-2 } & $\mathrm{Y}$ & $0.82 \pm 0.23$ & $2.54 \pm 0.44$ & $3.10 \pm 0.35$ \\
\cline { 2 - 5 } & $\mathrm{O}$ & $0.88 \pm 0.16$ & $1.53 \pm 0.34^{\#}$ & $1.73 \pm 0.33^{\#}$ \\
\hline
\end{tabular}

N o te. stLAF - stimulated level of LAF; unstLAF - unstimulated level of LAF; SI - Stimulation index of LAF production; ${ }^{*} p<0.05$ in compared with intact animals; ${ }^{*} p<0.05$ in compared with yuong animals after TBI.

lated by suboptimal lectin doses [3]. The extent of proliferation was measured by the fluorescence of the restored resazurin. The unit of LAF activity was defined as its amount in $\mathrm{ml}$ enough to increase thymocyte proliferation by $50 \%$ of the value of its maximal stimulation by Concanavalin A in suboptimal dose in the given test system. Stimulation index (SI) of LAF production shows the ratio of stimulated (stLAF) to unstimulated (unstLAF) level of LAF.

Results and discussion. It was found that on day 7 after TBI, macrophages of young rats responded by increasing the production of unstLAF. Stimulation of macrophages didn't increase the production of LAF. With injection of rIL-2 on day 7 and 14 after TBI, macrophages of young rats responded by increasing the production of stLAF (SI 1.86-2.85). The cells of older animals didn't respond by increasing LAF production $(\mathrm{SI} \sim 1$ ) on day 7 and 14 after TBI. Older injured rats that received rIL-2 injection showed significant stLAF increase only by day 14 after TBI $(\mathrm{SI}=1.72)$.

These results show that the strongest suppression of microphages' cytokine-producing function was found in older rats after TBI. The impact of age on the secretion of cytokines and chemokines by macrophages was not clearly defined. Most rodent-based researches have revealed an age-related decrease in the secretion of anti-inflammatory cytokines and chemokines extracted from microphages [4]. Our research has shown that rIL-2 injection significantly increased LAF production in young injured rats. In older rats, this effect was not as visible but by day 14 of observations the index of stLAF production was restored to normal levels. These data confirm that exogenic IL-2 is able to activate the functional characteristics of innate immunity cells and that is has a normalizing effect on the immune cells of the older animals.

\section{References}

1. Dinarello CA. Immunological and inflammatory functions of the interleukin-1 family. Annu. Rev. Immunol. 2009;27:519-550.

2. Rybakina EG, Shanin SN, Korneva EA. Cellular, Molecular and Signaling Mechanisms in Neuro-Immune Interactions Under Stress. Advances in Neuroimmune Biology. 2012;3(3-4):235-241.

3. Rosenwasser LJ, Dinarello CA. Ability of human leukocytic pyrogen to enhance phytohemagglutinin induced murine thymocyte proliferation. Cell Immunol. 1981;63(1):134-142.

4. Higashimoto Y, Fukuchi Y, Shimada Y, et al. The effects of aging on the function of alveolar macrophages in mice. Mech. Ageing Dev. 1993;69:207-217. 